\title{
ANALYSIS OF CHARACTER VALUES THROUGH ITP AND ATP TECHNOLOGY AS ONE OF THE INNOVATIONS IN LEARNING ELEMENTARY SCHOOL EDUCATION TO OVERCOME DEGRADATION
}

\section{Cut Nurul Zara Vonna, Fenti Retnoningrum, Indah Novita Sari, Muhamad Chamdani}

Universitas Sebelas Maret

cutvonna1@gmail.com

\section{Article History}

accepted 30/09/2018

approved $12 / 10 / 2018$

published 30/10/2018

\section{Keywords}

Globalization, Moral

Degradation, Character

Education, ITP and ATP.

\begin{abstract}
The development of time because of the existence of globalization led to moral degradation in children. To overcome the moral degradation of the child, it is necessary to have learning innovations in improving the quality of basic education which requires an analysis of character education using methods of observation and questionnaire by entering the results of analysis into ITP software (Development Task Inventory) and ATP (Analysis of Development Task). The existence of ITP and ATP can identify the level of development of aspects related to character education in primary school. Based on preliminary observations, it was found that many teachers did not know the level of children's character development. The article aims to: (1) educators can identify the level of students character (2) educators can design good learning based on the results of each student's character analysis. The conclusion of this study is that educators can develop children's character levels.
\end{abstract}

Social, Humanities, and Education Studies (SHEs): Conference Series https://jurnal.uns.ac.id/shes
p-ISSN 2620-9284

e-ISSN 2620-9292 


\section{PENDAHULUAN}

Perkembangan zaman yang pesat disebabkan oleh adanya globalisasi. Globalisasi itu sendiri dapat diartikan sebagai perubahan yang menyeluruh dan mempunyai dua potensiyaitu potensi positif dan potensi negatif. Terutama di Indonesia, hal ini menjadi suatu yang benar-benar harus diperhatikan. Perkembangan zaman akibat adanya globalisasi tersebut berpengaruh terhadap pergaulan anak yang semakin bebas. Adanya degradasi moral atau kemerosostan moral pada remaja saat ini sudah sangat mengkhawatirkan. Jika saja moral anak-anak bangsa hilang maka hancurlah bangsa itu. Sedangkan pengertian moral itu sendiri adalah hal yang menunjukkan sikap akhlak manusia (perbuatan yang dinilai) yang menjadi karakter jati diri manusia. Untuk itu diperlukan sebuah solusi berupa teknologi dalam penyelesaian masalah moral. Salah satu solusi yang dapat diterapkan yaitu dengan meningkatkan pendidikan karakter.

Pengertian karakter yaitu "sebuah usaha untuk mendidik anak-anak agar dapat mengambil keputusan dengan bijak dan mempraktikkannya dalam kehidupan seharihari, sehingga mereka dapat memberikan kontribusi yang positif kepada lingkungannya." (Megawangi, 2004: 95). Definisi lain mengenai pendidikan karakter yaitu "sebuah proses transformasi nilai-nilai kehidupan untuk ditumbuhkembangkan dalam kepribadian seseorang sehingga menjadi satu dalam perilaku kehidupan orang itu." (Gaffar, 2010: 1). Dalam definisi tersebut, terdapat ide pikiran penting. Pendidikan karakter siswa atau peserta didik adalah faktor utama dalam menghadapi degradasi moral, hal ini dikarenakan pendidikan karakter untuk siswa sangatlah penting. Tanpa disadari guru dan orang tua sering mengabaikan atau lupa untuk peduli terhadap karakter siswa. Hal ini dikarenakan guru dan orang tua lebih memperhatikan kemampuan knowlage atau pengetahuan siswanya. Guru dan orang tua tidak pernah melihat kemampuan karakter seorang anak sehingga tolak ukur suatu kesuksesan adalah dengan akademiknya. Anak pun akan merasa bahwa karakter atau moral itu tidaklah penting untuk dikembangkan atau dipertahankan.

Penelitian ini ditulis dengan adanya rumusan masalah berupa terjadinya globalisasi yang berdampak pada penurunan moral anak. Sehingga, artikel ini bertujuan agar pendidik dapat mengidentifikasi tingkat karakter siswa dan pendidik dapat merancang pembelajaran yang baik berdasarkan hasil analisis karakter masingmasing siswa.Dalam mengatasi degradasi moral anak tersebut, diperlukan adanya pendidikan karakter tentang bagaimana seorang pendidik memberikan bimbingan karakter dan mengidentifikasinya untuk kemajuan perkembangan seorang anak dalam segala aspek. Analisis karakter yang dilakukan oleh seorang guru kepada seorang anak sangat penting kegunaannya dalam mempengaruhi perkembangan segala aspek kehidupan yang dibutuhkan anak dalam menghadapi kehidupannya di masa depan nanti. Hal ini dapat juga mempengaruhi peningkatan mutu pendidikan agar pendidikan dimasa mendatang dapat terus melakukan inovasi dan tumbuh kembang kearah yang lebih baik lagi.

Untuk mencari siswa yang berkarakter pada saat ini sangatlah sulit, hal ini dikarenakan adanya pengaruh kemajuan teknologi, lingkungan sekolah dan tempat tinggal siswa. Sikap siswa pada zaman sekarang sangatlah berbeda dengan zaman dahulu, siswa zaman sekarang yang menghormati guru dan orang tua sudah sangat berkurang. Untuk itu dibutuhkan suatu teknologi yang mampu mengidentifikasi tingkat perkembangan karakteristik siswa, salah satunya yaitu ITP. ITP atau inventori tugas perkembangan adalah suatu cara untuk mengetahui tingkat perkembangan masingmasing individu. Seiring berjalannya ITP juga terdapat adanya program komputer yakni analisis tingkat perkembangan (ATP). Dalam hal ini kami akan membahas tiga nilai- 
niai karakter yang dapat di ukur menggunakan ATP, yang bertujuan dalam mengatasi degradasi antara lain Religius, Kesadaran Tanggung jawab, dan Kematangan Emosional.

Diharapkan dengan adanya pembahasan ini guru dan orang tua tersadar dari kekeliruan yang turun temurun dan agar generasi penerus bangsa menjadi anak yang baik, berbudi pekerti luhur, bertanggung jawab dan dapat mengendalikan emosi nya yang berdampak pada perkembangan karakter.

\section{METODE}

Dalam penelitian ini dilakukan dengan metode survei. Surveiadalah penelitian yang berusaha mengungkapkan opini, pendapat ataupun pandangan dari masyarakat terhadap kasus yang khusus (Sanjaya, 2013: 38). Pendekatan yang digunakan adalah pendekatan deskripsi kualitatif-kuantitatif yang menggunakan analisis data, pendeskripsian suatu objek, penggambaran suatu permasalahan, dan menyuguhkan sejumlah data sesuai dengan fakta pada lapangan secara sistematis dan interpretasi yang tepat. Adapun langkah-langkah yang ditempuh dalam deskripsi kualitatifkuantitatif yaitu perumusan masalah, melakukan studi pustaka, menentukan prosedur pengumpulan data yang berhubungan dengan alat pengumpulan data dan sampel data, menentukan prosedur pengelolaan informasi atau data, menganalisis data sesuai dengan permasalahan, dan menarik kesimpulan penelitian serta memaparkan hasil analisis.

Teknik pengumpulan data dalam penelitian ini yaitu menggunakan angket yang diberikan saat observasi di SD. Selain itu menggunakan teknik studi pustaka dengan melakukan pencarian referensi yang relevan dengan permasalahan seperti buku, jurnal, artikel, dan melakukan pengamatan penlitian secara langsung terhadap siswa SD. Penelitian ini menggunakan metode analisis data yang secara singkat pengertiannya yaitu proses dimana data diurutkan dengan suatu pola dan pengorganisasiannya menjadi suatu susunan data. Pola tersebut antara lainmengumpulkan data, menganalisis data, menarik kesimpulan, dan memaparkan hasil analisis.

\section{HASIL DAN PEMBAHASAN}

Globalisasi adalah suatu proses dimana antar individu, antar kelompok, dan antar negara saling berinteraksi, bergantung, terkait, dan mempengaruhi satu sama lain yang melintasi batas negara.Sedangkan menurut Malcom Waters globalisasi adalah sebuah proses sosial yang berakibat bahwa pembatasan geografis pada keadaan sosial budaya menjadi kurang penting, yang menjelma didalam kesadaran orang. Dari adanya globalisasi timbullah degradasi moral yang artinya penurunan tingkah laku manusia akibat tidak mengikuti suara hati karena kurangnya kesadaran diri akan kewajibannya.

Solusi yang dapat diberikan dalam permasalahan tersebut yaitu dengan menciptakan suatu inovasi pembelajaran yang harus berdampak pada perbaikan individu menjadi lebih baik lagi. Salah satu inovasi pembelajaran tersebut yaitu dengan menggunakan teknologi ITP (Inventori Tugas Perkembangan) dan ATP (Analisis Tugas Perkembangan) yang dapat di manfaatkan sebagai alat pengukur tingkat perubahan karakter individu dengan mempertimbangkan aspek religius, aspek tanggung jawab, dan aspek emosional. ITP dan ATP itu sendiri dapat membantu proses mengidentifikasi nilai-nilai karakter. Pendidikan karakter adalah "sebuah usaha untuk mendidik anak-anak agar dapat mengambil keputusan dengan bijak dan mempraktikkannya dalam kehidupan sehari-hari, sehingga mereka dapat memberikan kontribusi yang positif kepada lingkungannya." (Megawangi (2004: 95). Definisi lainnya yaitu "sebuah proses transformasi nilai-nilai kehidupan untuk ditumbuhkembangkan 
dalam kepribadian seseorang sehingga menjadi satu dalam perilaku kehidupan orang itu." (Gaffar, 2010: 1). Dalam definisi tersebut, ada tiga ide pikiran penting, yaitu proses transformasi nilai-nilai, ditumbuhkembangkan dalam kepribadian, dan menjadi satu dalam perilaku. Jadi dapat disimpulkan bahwa pendidikan karakter adalah sebuah usaha untuk mendidik anak-anak melalui proses traspoformasi nilai- nilai kehidupan.

Dalam mengidentifikasi karakter seorang anak, diperlukan nilai -nilai karakteristik yaitu antara lain: Religius, jujur, toleransi, disiplin, kerja keras, kreatif, mandiri, demokratis, rasa ingin tahu, semangat kebangsaan, cinta tanah air, menghargai prestasi, bersahabat/komuniktif, cinta damai, gemar membaca, peduli lingkungan, peduli sosial dan tanggung jawab. Dalam penulisan ini, digunakan tiga aspek yang menyangkut tentang karakter yaitu aspek religius, tanggung jawab, dan kematangan emosional.Dalam pelaksanaan pengambilan data ITP, diperlukan adanya Inventori Tugas Perkembangan yang berupa beberapa butir soal yang terdiri dari pernyataan yang mengukur setiap sub aspek; tingkat perkembangan siswa dapat dilihat dari skoryang di peroleh pada setiap aspek; besar skor yang diperoleh menunjukan tingkatperkembangan siswa; dan angket ITP untuk setiap tingkat pendidikan memilikijumlah soal yang berbeda.

Untuk membantu pengerjaan ITP dapat menggunakan aplikasi ATP yang dapat beroperasi sebagai alat pengolahan data secara cepat yang terdiri dari analisis kelompok (profil kelompok, grafik distribusifrekuensi untuk setiap aspek, grafik distribusi frekuensikonsistensi, delapan butir tertinggi dan terendah) dan analisisper individu (profil individual, distribusifrekuensi nilai, delapan butir tertinggi dan terendah untukindividu tersebut). Kemudian data yang sudah diolah tersebut dapat divisualisasikan dalam bentuk grafik, diagram, ataupun histogram dengan pengelompokan data yang terdiri dari pengelompokan siswa berdasarkan kriteria tertentu dan penggabungan kelompok. Aplikasi ATP ini dapat bekerja secara cepat dan akurat yang tentunya akan memudahkan pembacaan data yang tepat oleh konselor atau mahasiswa calon pendidik.

Dalam penelitian ini, penulis mengambil satu sampel nama yaitu Safril Faturohman yang berasal dari SD Negeri 6 Panjer. Dalam grafik ATP ditampilkan 8 butir tertinggi dan 8 butir terendah yang dimilki oleh Safril Faturohman setelah melakukan pengisian angket soal yang mana bertujuan dalam menganalisis perkembangan karakter Safril faturohman.

Tabel Tingkat Perkembangan Individu Safril Faturohman

\begin{tabular}{|c|c|c|c|c|c|c|c|c|}
\hline \multirow[t]{2}{*}{$\mathrm{NO}$} & \multicolumn{4}{|c|}{ TP } & \multicolumn{3}{|c|}{ SKOR } & \multirow[t]{2}{*}{ KETERANGAN } \\
\hline & SDI & KOM & PLD & MP & 1 & 2 & 4 & \\
\hline 1 & & & & $\checkmark$ & $\checkmark$ & & & Landasan hidup religius \\
\hline 2 & $\checkmark$ & & & & & & $\checkmark$ & Kesadaran tanggung jawab \\
\hline 3 & $\checkmark$ & & & & & & $\checkmark$ & Kematangan emosional \\
\hline
\end{tabular}

Sesuai dengan pokok bahasan mengenai aspek religius, tanggung jawab dan kematangan emosional dapat dikemukakan bahwa pada Tabel Tingkat Perkembangan Individu Safril Faturohmantelah mencapai kematangan emosional yaitu memperoleh skor 4 dengan TP (Tingkat Perkembangan) SDI (Sadar Diri) dan juga telah mencapai kesadaran tanggung jawab yaitu memperoleh skor 4 dengan TP (Tingkat Perkembangan) SDI (Sadar Diri). Dalam hal ini, tingkat emosional dan rasa tanggung jawab Safril Faturohman telah mencapai taraf yang baik dan hanya perlu bimbingan sedikit agar dapat mempertahankan sifat dari aspek tersebut. Jika kematangan emosioanal dan rasa tanggung jawab seorang anak telah mencapai SDI (Sadar Diri) 
maka anak tersebut sudah dapat dan mampu mengendalikan karakter moral yang ada pada dirinya. Namun, pada aspek landasan hidup religius saudara Safril Faturohman masih tergolong rendah karena hanya memperoleh skor 1 dengan TP (Tingkat Perkembangan) MP (Impulsif), sehingga membutuhkan penanganan yang lebih lanjut antara guru atau pendidik dan orang tua dalam rangka meningkatkan kualitas moral dan karakter anak. Tingkat MP (Impulsif) adalah tingkat paling rendah dalam pengukuran aspek yang mana membutuhkan bimbingan secara sistematis. Jika saja hal ini dibiarkan tanpa adanya bimbingan lebih lanjut secara mendalam, maka sikap religius tersebut perlahan-lahan akan musnah. Bisa saja di masa yang akan datang saudara Safril Faturohman malas untuk mengenal Tuhan atau melaksanakan perintah agamanya. Hal ini juga berdampak buruk pada moral karakter seorang anak, dimana moral akan hilang dan karakter akan hancur sehingga dapat terjadi penyimpangan sosial.

Dari sampel tersebut dapat dianalisis bahwa aspek religius merupakan aspek utama pembentuk moral dan karakter seorang anak. Jika aspek religiusnya rendah maka tidak akan ada gunanya setinggi apapun aspek yang lain. Di era global ini harus terdapat aspek religius yang kuat pada setiap individu agar dapat menjadi tameng utama dalam pembentukan moral dan karakter. Kemudian yang kedua yaitu aspek kesadaran tanggung jawab yang juga berhubungan dengan moral dan karakter seorang anak dimana rasa tanggung jawab dalam segala hal sangat dibutuhkan pada fase anak-anak sampai lansia. Yang terakhir yaitu aspek kematangan emosional yang juga berhubungan dengan perkembangan moral dan karakter seorang anak dalam era global ini. Kematangan emosi menjadi faktor ketiga dalam proses membedakan mana yang benar dan mana yang buruk dalam menentukan solusi pada suatu permasalahan.

\section{SIMPULAN}

Dari pembahasan diatas maka dapat disimpulkan bahwa penggunaan software ITP dan software ATP dalam inovasi pendidikan yang berkaitan dengan peningkatan pendidikan karakter dan moral anak untuk mengatasi degradasi moral di era globaldapat meningkatkankualitas proses pendidikan sehingga hasil belajar siswadapat meningkat.Perbaikan inovasi pendidikan dengan menggunakan ITP dan ATP inimemberi pengaruh signifikan terhadap peningkatan moral dan karakter siswa baik dalam hal konsep maupun dalampraktik dengan berbasis analisis aspek religius, aspek keasadaran tanggung jawab, dan aspek kematangan emosional. Jika aspek religius, aspek kesadaran tanggung jawab dan aspek kematangan emosioanal meningkat maka terdapat kemungkinan yang sangat kecil seorang indvidu mengalami egradasi moral.Inovasi pembelajaran ini mengantarkan siswamemiliki kemampuan dalam mengaplikasikan karakter baiknyasecara langsung di sekolah maupun lingkungan sekitar dan mempunyai pengaruh positif dalam pengembangankompetensi siswa.

\section{DAFTAR PUSTAKA}

Ana, dkk. (2016). Laporan Hasil Observasi Analisis Tugas Perkembangan PesertaDidik Kelas 3 SD Alam Lukulo. Laporan Penelitian FKIP PGSD Kebumen. Tidak diterbitkan.

Gaffar, M. \& Fakri. (2010). Pendidikan Karakter Berbasis Islam. Yogyakarta: Makalah Seminar. 
Megawangi, Ratna. (2004). Pendidikan Karakter: Solusi yang Tepat untuk Membangun Bangsa. Bogor: Indonesia Heritage Foundation.

Priyatmono, M.A. dkk. (2017). Aspek Kematangan Berfikir (Intelektual) Anak SD di Wilayah Kebumen, UNS.

Rantauwat, H.S. (2014). Pengembangan Karakter Siswa Melalui Bermain Peran: Jurnal IImiah Guru "COPE” No 01, SD Dadapsari.

Salimi, M. dkk. (2016). Prosiding Seminar Nasional Inovasi Pendidikan: Inovasi Pembelajaran Berbasis Karakter dalam Menghadapi Masyarakat ASEAN. Surakarta: UNS Press.

Salimi, M. dkk. (2017). Inovasi Pendidikan: Bunga Rampai Kajian Pendidikan Karakter, Literasi, dan Kompetensi Pendidik dalam Menghadapi Abad 21. Salatiga: Widya Sari Press Salatiga.

Sanjaya, W. (2013). Penelitian Pendidikan. Jakarta: PT Fajar Interpratama M 